\title{
Assessing climate change mitigation and adaptation strategies and agricultural innovation systems in the Niger Delta
}

\author{
Michael E. Ikehi • Florence O. Ifeanyieze • Francis M. Onu • \\ Toochukwu E. Ejiofor · Clara. U. Nwankwo
}

Accepted: 19 January 2022 / Published online: 18 February 2022

(C) The Author(s), under exclusive licence to Springer Nature B.V. 2022

\begin{abstract}
Climate change and its impacts on agriculture have been widely discussed at national and global levels. An important aspect of the discussion has been adaptation/mitigation approaches. Consequently, several strategies have been suggested as measures to ensure agriculture remains productively profitable. However, food security especially in critical times, such as the lockdown during the COVID-19 pandemic proved to be a challenge even for regions naturally endowed for agriculture. The study evaluated research recommended strategies, and further examined the innovativeness of the strategies in fostering sustainable agricultural innovation system (AIS) in the Niger Delta. The study relied on both secondary and primary data; analysed 129 previous studies and gathered responses from 282 extension agents. The study introduces a method for assessing the innovativeness of strategies by calculating their rated values on five traits. Findings revealed the issues and implications of adopting most recommended strategies and the place of most strategies in fostering AIS. The study highlights the possible reasons why farmers fail to adopt most strategies as suggested by studies on climate change in the region. Based on the findings, recommendations were made
\end{abstract}

M. E. Ikehi $(\bowtie) \cdot$ F. O. Ifeanyieze $\cdot$ F. M. Onu

T. E. Ejiofor · C. U. Nwankwo

Department of Agricultural Education, University of Nigeria, Nsukka 410001, Enugu State, Nigeria e-mail: michael.ikehi@unn.edu.ng on the way forward. The study adds to the scanty discussion of climate change and AIS at regional levels, particularly in the climate change prone and oil rich Niger Delta region. The study offers a novel approach for scoring innovations in agriculture.

Keywords Agricultural research - Extension agents · Food production · AIS · Innovative Index · Niger Delta

\section{Introduction}

Climate is a fundamental element of the environment on which agriculture and other essentials of life largely depend. Prolonged alterations in weather conditions results in climate change. Climate change is the variation in the statistical distribution of average weather conditions in an area over a period of time (Baede, 2015; Mach et al., 2016; Mendlik \& Gobiet, 2016; Junk et al., 2016; IPCC, 2016). The changes affect the lives of people, plants and animals in many ways, especially in food and feed production, availability and use of water, health risks, land use pattern, production processes, cost and profitability of agribusinesses (Atubi, 2015; Ordinioha \& Brisibe, 2013; Saleh et al., 2017). Climate change impacts on agriculture have been discussed in several studies (Apata, 2010; Ifeanyieze et al., 2016; Nzeadibe, et al., 2012). Important aspects of the discussion border on adaptation and mitigation approaches (Onu \& Ikehi, 2016). 
Consequently, several adaptation and mitigation strategies have been suggested for sustainable and profitable agriculture (Enete, 2014; Ifeanyieze et al., 2016; Ikehi et al., 2014; Lambert, 2014; Okringbo \& Ominikari, 2017), especially in prone areas like the Niger Delta.

The Niger Delta region is described as one of the richest wetlands in Africa for agriculture (Nwilo $\&$ Olusegun, 2007). The region contributes $80 \%$ of the Nigeria's revenue and $74 \%$ of export earnings (UNDP, 2006). Large aspects of the region are predominantly rural and the people are among the world's poor even with the vast wealth of oil (Ebegbulem et al., 2013; Jackson et al., 2016; Linden \& Pålsson, 2013). The major economic activity of the communities in the region is either land-based crop farming or water-based fish capture/culture (Aweto, 2011). However, these economic activities are largely influenced by the variability of climate. Reported evidences of climate change in the region include, but are not limited to, increase in temperature, changes in rainfall pattern, high soil temperature leading to crop failure, rising sea levels leading to flooding of farmlands and roads, expansion of the range of tropical diseases leading to crop, animal, and human health hazards (Idrisu, 2016; Ifeanyieze et al., 2016; Ikehi et al., 2021; Ito \& Ugbome, 2017; Okringbo \& Ominikari, 2017; Osuoha \& Fakutiju, 2017; Schick et al., 2018).

These effects have impacted on farming businesses in the area in varying degrees, and have led to harsh economic implications. As climate change impacts have been reported in studies (Blanc, 2011; Enete, 2014; Ikehi et al., 2021), recommendations are expected to guide farmers in coping with impeding or trending impacts to ensure sustainable farming and better standard of living for the farming families. However, in the Niger Delta susceptibility of agriculture to the impacts of climate change remains high (Nwilo \& Olusegun, 2007) adoption levels for suggested strategies seem low (Moram, 2011; Nzeadibe et al., 2012) and crop production output is poor (Ikehi et al., 2021; Okringbo \& Ominikari, 2017). Research has often had many factors to blame for the poor adoption of suggested strategies in the region. Some studies blamed low adoption of researchrecommended strategies on the coastal nature of the region, presence and dependence on crude oil (Onu \& Ikehi, 2016), aggravating precursor of climate change such as environmental pollution on the account of oil exploration and gas flaring (Agbonifo, 2016; Emuedo \& Emuedo, 2018; Schick et al., 2018), low awareness level (Ifeanyieze et al., 2016; Ikehi et al., 2014), poor policy framework of government and its agencies (Amobi \& Onyishi, 2015) and low adoption capacity of the farmers (Moram, 2011; Niles et al., 2016; Nzeadibe et al., 2012) among others. While some or all of these factors may likely be the case, this study focused on how innovative the recommended strategies were for adoption. The study focused on how the nature (whether adaptation or mitigation), actors, and cost implication affects the adoption of suggested strategies in the Niger Delta. The study further explored how most research-recommended strategies foster Agricultural Innovation Systems (AIS) at farm levels.

AIS is a grid of important actors dedicated to introducing new products, processes, and methods in economically feasible and socially acceptable ways while relying on institutions and policies that together influence the achievement of desired goals for agriculture. The system links people, infrastructure and institutions together for the purposes of generating, sharing, and utilising new or improved existing knowledge and technology for agriculture. AIS emphasizes knowledge generation (through research agencies/ institutions, researchers and agricultural educators), diffusion (through extension agents and advisory services), application (by the farmers) and the interactions among relevant players (such as governmental/ nongovernmental agents and policy institutions) in the agricultural sector (Anandajayasekeram, 2011; Hall, 2007, 2012; Klerkx \& Aarts, 2013; Klerkx et al., 2010; Rajalahti, 2009; Saravanan \& Suchiradipta, 2017; Schut et al., 2015; Sulaiman, 2015; World Bank, 2012). In a functional AIS, farmers are at the heart of the knowledge triangle and the interactions among actors/stakeholders ensure flow of innovations and feedbacks (World Bank, 2012) for solving agricultural problems such as climate change issues. See Fig. 1.

The drive to solve climate change and other problems in agriculture has led to increased sponsorship for research in the sector (Hall, 2012; Rajalahti, 2009). A report by Rajalahti et al. in Hall (2012) indicated that World Bank in the past 20 years has spent well over US $\$ 2.5$ billion for agricultural extension, research, and development. 
Fig. 1 IIIustration of AIS. Source: Authors, 2021

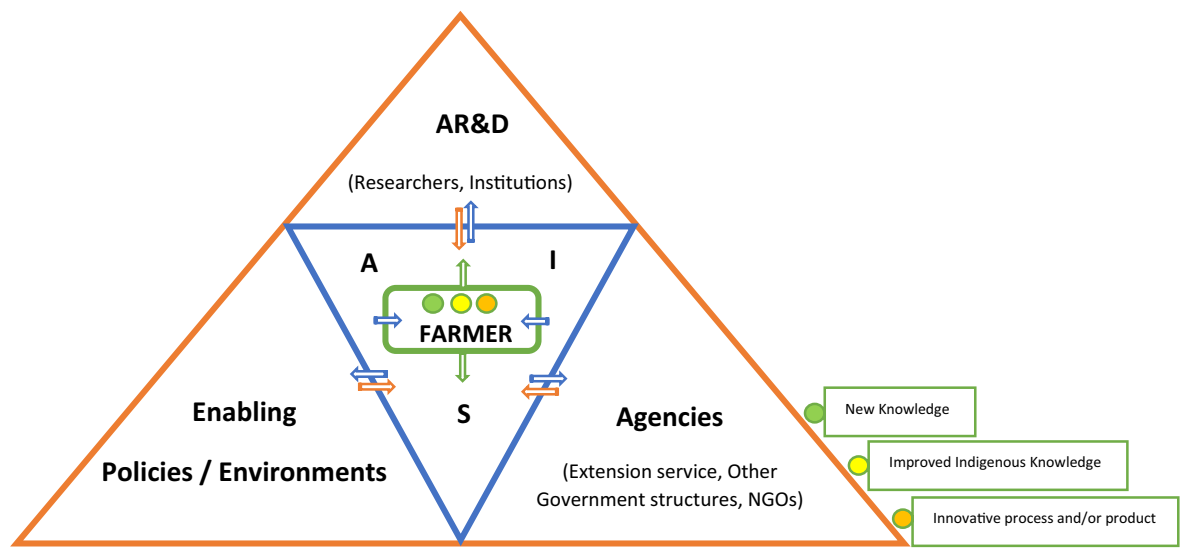

According to the report, the gains in investing in agricultural researches have been fairly successful in increasing available knowledge but have not fully fostered the use of information and inventions in agriculture as well as ensured adequate food production (Hall, 2012). For outcomes of agricultural researches to be useful to the end users, they are to be properly linked to the users, the structure or institutions that aid them and ensure users' ability to respond to changes through AIS (Nzeadibe et al., 2012; Klerkx et al. 2015; Niles et al., 2016; Devaux et al., 2018). The study evaluates most recommended strategies and further explore how these strategies align with AIS at farm level, to better understand climate change issues in the Niger Delta region. The study contributes to the scanty literature on climate change and agriculture in the Niger Delta and AIS in Africa, especially in Nigeria.

\section{Objectives of the study}

The study specifically;

1. Evaluated research-recommended strategies based on frequency of recommendation by studies, actors involved, and the cost implication of adoption of the strategies for farmers in the region.

2. Examined the innovativeness of the researchrecommended strategies in fostering AIS in the Niger Delta.

\section{Materials and methods}

The study was mix-method research involving both a narrative review and survey. The study analysed both qualitative and quantitative data. The qualitative aspect reviewed published literature that focused on climate change adaptation and mitigation strategies in the Niger Delta. The quantitative aspect collected field data that were used to evaluate the innovativeness of research-recommended strategies.

\section{Area of the study}

The study was carried out in Niger Delta region of Nigeria (see Appendix). The region is an oil rich one and occupies about $12 \%$ of the land mass of Nigeria with an area of about $70,000 \mathrm{~km}^{2}$ (Ikehi et al., 2014; Ugolor, 2004). The rivers, creeks and estuaries in the region measures about $2370 \mathrm{~km}^{2}$ while stagnant swamps cover about $8600 \mathrm{~km}^{2}$ (Ugolor, 2004). With mangrove forests ranging between 5000 and $8580 \mathrm{~km}^{2}$ of land, the region is home to numerous species of aquatic and terrestrial plants and animals (Ikehi et al., 2014; Nwilo \& Olusegun, 2007). The region is home to over 30million people (Stakeholderdemocracy, 2020). An estimated $70 \%$ of the region's population live below the poverty line (UNDP in Foundation for Partnership Initiatives in the Niger Delta, PIND, 2011), in spite of being the economy might of the nation-a resource course case. According to PIND (2011) over 62\% of the region's population are 30 years or younger and are mostly unemployed-underlining the high youth restiveness in the 
region. With over 50\% absorption of the unemployed, agriculture remains the largest employer of labour in most Niger Delta states (PIND, 2011). The region occupies a large area of Nigeria's most fertile land suitable for the production of important cereals such as maize, tubers such as cassava, vegetables, palm, rubber and many other crops (Abisola, 2013; Rosemary et al., 2012). Major agricultural activities in the region include fish farming, capture and processing, crop production, harvesting of forest resources/ games, and marketing of agricultural produce. This study focused on this region because of the high presence of climate change precursors, the economic importance of the region and its agricultural sector to the Nigerian state economy and for the need to proffer solution to the risen impacts of climate change in the region.

\section{Participants}

The region has a population of 952 extension agents as at 2018. The study adopted Taro Yamane formula for determining sample size (Ikehi et al., 2019), and a total of 282 extension agents were drawn from all nine states. Proportionate percentage contribution to the population by states was used to determine the number of respondent extension agents for each state. The respondents were sampled through simple random approach. Extension agents (EA) were the target respondents for the study because of their experience in interacting with farmers and other stakeholders in agriculture. They are often described as the bridge for reaching the farmers (Sulaiman, 2015). Table 1 presents the distribution of the respondents according to state.

\section{Instruments for data collection}

Two instruments were used for data collection. For the first part of the study, a structured document review guide was used. The document review guide contained a table with spaces where identified strategies from reviewed studies was recorded. The instrument was later modified into a rating scale for collecting primary data from respondents.

For the second part of the study, a rating scale was used. Items on the instrument, which include
Table 1 Distribution of respondents

\begin{tabular}{lccc}
\hline State & No. of EA & \% Contribution & $\begin{array}{l}\text { Participant EA } \\
\text { from the state } \\
\text { Sample }\end{array}$ \\
& Population & & 33 \\
Abia & 112 & 11.8 & 69 \\
Akwa-Ibom & 231 & 24.3 & 4 \\
Bayelsa & 12 & 1.3 & 25 \\
Cross River & 31 & 8.7 & 9 \\
Delta & 83 & 3.3 & 39 \\
Edo & 132 & 13.9 & 32 \\
Imo & 108 & 11.3 & 37 \\
Ondo & 126 & 13.2 & 34 \\
River & 117 & 12.2 & 282 \\
Total & 952 & 100 & \\
\hline
\end{tabular}

strategies identified in the reviewed literature during the first part of the study were enlisted for rating. Respondents were requested to rate the items on a scale of 0 (zero) to 10 (ten) for novelty, improvement, economics, widespread, and interaction. For the rating, 0 indicated total absence of the trait, and 10 indicated high possessiveness of the rated traits in fostering AIS. The AIS "perspective provides a framework for analysing how knowledge is exchanged and how change occurs in a given society" by examining innovation's (whether process or product) functionality and interactions of various actors in agriculture (Anandajayasekeram, 2011 p. 8)]. According to Anandajayasekeram (2011), the four basic requirements (traits) for examining an innovation to determine whether it aligns with AIS are that it is novel or reinvented, better than what currently exists (improvement), economically viable (and socially desirable), and commonly adopted (widespread). A fifth and important trait would be the level of communications (interactions) among stakeholders in helping farmers adapt.

The traits were explained to the respondents to enable them rate each strategy properly. The novelty trait measured how new or modified each identified strategy were to the farmers in adjusting to impacts of climate change in the region. The improvement trait explained how adopting each strategy helped the farmers to enhance production and adjust to climate change impacts. The economic trait measured how cost effective adopting each strategy was to the farmers. The widespread trait evaluated how well 
accepted and socially conforming each strategy is/ was among farmers in their locality. The interaction trait addressed the level of linkages existing or needed among relevant stakeholders to ensure effective adoption of each strategy.

\section{Validation and reliability of the instruments}

The draft of the review guide and the rating scale were face validated by five experts contacted on ResearchGate. The experts made structural and content corrections on the instruments for clarity and adequacy. To establish the reliability for the coding procedure for the review guide, three studies on climate change mitigation and adaptation in Northern Nigeria were selected based on the inclusion criteria and scored by three research assistants. Across studies and variables, inter-rater agreement was 0.80 (translating to $80 \%$ data agreement) which is greater than 0.50 (50\% data agreement benchmark) indicating that the instrument was reliable (Graham \& Perin, 2007; Paustian-Underdahl et al., 2014).

A pilot study was carried out to determine the reliability of the rating scale. Ten (10) copies of the validated rating scale were sent to 10 extension agents in the Northern part of Nigeria. However, only 7 copies were return and analysed. Data from the returned copies were entered into SPSS (v.22) and Cronbach Alpha formula was used to calculate the reliability index, which yielded 0.84 coefficient value indicating that the instrument has high internal consistency thus reliable for use for the study.

\section{Data collection and analysis}

Data collection spanned a period of three months, from February to April, 2020. The study relied on both primary and secondary data. The study was divided into two phases.

\section{Phase I}

The phase one adopted narrative review design, and involved the collection of secondary data to address research objective one. To achieve this objective 1871 empirically researched studies that focused on climate change in the Niger Delta were downloaded and evaluated. The phase began with a search for existing literature and an internet search using the strings 'climate and Niger Delta', 'climate change in Niger Delta', 'agricultural production in Niger Delta', and 'climate, agriculture and Niger Delta' in Google scholar, Scopus and Web of Science. Among the 1871 obtained literature, 129 were selected after applying three-inclusion criteria: the study was must be (1) carried out in (any part of) the Niger Delta, (2) an empirical research that presented findings on adaptation or/and mitigation strategies, and (3) carried out between 2008 and 2018. The rationale for focusing on studies between 2008 and 2018 was to allow inclusion of a decade's worth of research on agriculture and climate change in the region. Also, this period witnessed high turnout of researches that focused on climate change and agriculture in the Niger Delta. The selected works were carefully studied. Suggested strategies were extracted and organized. Strategies that were similar (including those with different nomenclature) across manuscripts were grouped as one to avoid duplication of information.

Frequency count and simple percentage were used to analyse the univariate data. On the bases of approach, strategies were classified as adaptation or mitigation or as both. Any strategy geared towards adjusting crop production to existing impacts was regarded as adaptation (A), while strategies practiced now but aimed at future correction or prevention of causalities from climate change were regarded as mitigation (M) approaches. Data was also analysed based on frequency of recommendation by studies, who implements the strategy at final (farm) level, and whether adopting the strategy attracted additional cost (cost implicative-CI or Not-NC) for crop farmers in Niger Delta.

\section{Phase II}

The phase II of the study adopted survey design, and involved the collection of primary data using a rating scale. This section addressed research objective two. Physical administration of the copies of the instrument was not possible as a result of the movement restrictions and social distancing order during the COVID-19 lockdown. Copies of the rating scale were e-mailed to the respondents along with instructions 
for completing the instrument. Telephone interviews were conducted for respondents with no e-mail. Follow-up telephone calls were also made to respondents who responded through e-mail to clarify any possible misunderstanding. A total of 282 copies of the instrument were successfully completed and used for data analysis. Mean was used to analyse the nominally distributed data: the average of the ratings by the respondents for the traits for each strategy was calculated. A trait with a rating higher or equal to five $(\geq 5)$ indicated significant possession.

To interpret the innovativeness of each strategy, the sum of the averages of the rated traits were calculated. Any strategy with a sum of averages greater than twenty-five $(\geq 25)$ was regarded as innovative enough to foster AIS in the Region. The sum of the ratings is the Innovative Index Value (IIV). A high IIV indicated high innovativeness and alignment to AIS. The study assumed that the level of expression of the traits is a possible indication of the innovativeness of the strategy. Data were present in Tables and Figures.

\section{Results}

Economics of research recommended strategies

Data on Table 2 presents the analysis of the strategies for coping with the impacts of climate change on crop production as suggested by existing studies in the Niger Delta. Among the 30 listed items, water collection and utilization for farming were the most recommended strategies as indicated by 54 existing studies. The least was the establishment of food grain reserves as indicated by only 21 studies. Adaptation practices were the most suggested (23 out of 30; $77 \%$ ). Mitigation practices were fewer (3 out of 30; $10 \%$ ). Some suggested strategies (4 out of $30 ; 13 \%$ ) can be classified as both adaptation and mitigation practices, such as controlling deforestation. Data on actors involved in carrying out the suggested strategies indicate that majority ( 21 out of $30 ; 70 \%$ ) of research recommended strategies directly involve the efforts of the farmer. Some (3 out of 30;10\%) of the strategies require the joint efforts of the farmer, relevant governmental and non-governmental agencies for adoption/implementation while the remaining (6 out of $30 ; 20 \%)$ strategies mainly involve the efforts of governmental and non-governmental agencies. The implications are that items with $F \& A / G$ require the farmers to collaborate with local/foreign governmental/non-governmental agencies while items with $\mathrm{A} / \mathrm{G}$, such as proclamation of laws banning activities like gas flaring, is the responsibility of government and her agencies. However, all suggested strategies will likely involve some input from the farmers for actualization. Data on Table 2 further reveal strategies that are cost implicative (CI) and those that attracts no direct or significant cost (NC) for the farmer. Out of the 30 recommended strategies, 13 are cost implicative, meaning that adopting such strategies will significantly increase the cost of cultivation for the crop farmer. Example of such strategies include increasing labour, land reclamation, and flood diversion. The remaining 17 strategies, such as changing planting/ harvesting dates and using zero tillage, attracts little to no direct cost for the crop farmer.

Innovativeness of research-recommended strategies and alignment to AIS

Data on Fig. 2 presents the ratings of EA on the innovativeness of the research recommended strategies for coping with the impacts of climate change in the region. On the chart, SN1-SN30 corresponds to the 30 suggested strategies on Table 2; where SN1 represents "Irrigation/sinking boreholes, construction of dams/ditches for water collection", and SN30 is for "Establishment of food grain reserves". Majority of the ratings on novelty indicate that a good number of the suggested strategies are new to the farmers or has been modified. Strategies rated to be most novel to the farmers in the region include SN15, SN17, SN20, SN23 and SN29 with a value of 7. The least novel is SN16 with a value of 3. Strategies considered to have improved farming significantly in the region include SN23 and SN28 with a value of 9, and the least was indicated to be SN8 with a value of 2. On how economical the strategies are, SN29 with a rated value of 9 was the most economical for the farmers, and SN13 was the least economical with a value of 2 . The most commonly adopted strategy (widespread) is SN9 with a value of 8 while the least widespread strategies are SN26 and SN29. Strategies with the highest (current) involvement of relevant stakeholders (including the farmers) were SN9 and SN19 with rated interactivity value of 4 while the least were SN1, SN8 and 
Table 2 Economics of the strategies for coping with the impacts of climate change on crop production in the Niger Delta

\begin{tabular}{|c|c|c|c|c|c|}
\hline SN & Suggested strategies & $\mathrm{F}$ & $\mathrm{T}$ & WI & $\mathrm{CF}$ \\
\hline & Irrigation/sinking boreholes, construction of dams/ditches for water collection & 54 & A & $\mathrm{F} \& \mathrm{~A} / \mathrm{G}$ & $\mathrm{CI}$ \\
\hline & Protection of water sheds/mulching/cover cropping & 53 & $\mathrm{~A} / \mathrm{M}$ & Farmer & $\mathrm{NC}$ \\
\hline & Increased labour/weeding & 53 & A & Farmer & $\mathrm{CI}$ \\
\hline & Cultivation of improved varieties that are well acclimated to local factors & 48 & A & Farmer & $\mathrm{NC}$ \\
\hline & Changing planting and harvesting dates & 47 & A & Farmer & $\mathrm{NC}$ \\
\hline & Mixed farming/cropping and inter-cropping & 45 & A & Farmer & $\mathrm{NC}$ \\
\hline & Planting of tree (reforestation/afforestation) & 43 & M & $\mathrm{F} \& \mathrm{~A} / \mathrm{G}$ & CI \\
\hline & Leaving farming/changing from production to marketing & 37 & A & Farmer & $\mathrm{CI}$ \\
\hline & Land/crop rotation/bush fallow/shifting cultivation & 36 & A & Farmer & $\mathrm{CI}$ \\
\hline & Use of organic manure & 35 & A & Farmer & $\mathrm{NC}$ \\
\hline & Changing tillage practices (zero or minimum) & 32 & A & Farmer & $\mathrm{NC}$ \\
\hline & Raising of dykes, contour bund, ridges and bridges & 31 & A & Farmer & CI \\
\hline & Reclamation/draining of wetland/sand filling/culverting & 30 & A & $\mathrm{F} \& \mathrm{~A} / \mathrm{G}$ & CI \\
\hline & Stoppage/banning/controlling of deforestation /excessive harvesting of timber/fire wood & 30 & $\mathrm{~A} / \mathrm{M}$ & $\mathrm{A} / \mathrm{G}$ & $\mathrm{NC}$ \\
\hline & Migration from climate risk areas & 29 & A & Farmer & $\mathrm{NC}$ \\
\hline & Increase in the use of chemicals herbicide, insecticide, pesticide & 28 & A & Farmer & CI \\
\hline & Setting up windbreaks/shelter belts & 28 & $\mathrm{~A} / \mathrm{M}$ & Farmer & $\mathrm{CI}$ \\
\hline & Increase usage of fertilizer & 28 & A & Farmer & CI \\
\hline & Relying on weather information & 28 & A & Farmer & $\mathrm{NC}$ \\
\hline & Construction of elevated homesteads and farmsteads & 27 & A & Farmer & $\mathrm{CI}$ \\
\hline & Stopping/banning/controlling bush burning & 26 & $\mathrm{~A} / \mathrm{M}$ & $\mathrm{A} / \mathrm{G}$ & $\mathrm{NC}$ \\
\hline & Changing planting depth & 26 & A & Farmer & $\mathrm{NC}$ \\
\hline & Quick processing of crops to minimize post-harvest losses during storage & 25 & A & Farmer & $\mathrm{NC}$ \\
\hline & Proclamation of laws reducing/banning/controlling activities such as gas flaring & 23 & M & $\mathrm{A} / \mathrm{G}$ & $\mathrm{NC}$ \\
\hline & Expansion of cultivated area & 23 & A & Farmer & $\mathrm{CI}$ \\
\hline & Adjusting sales price/Hedging & 23 & A & Farmer & $\mathrm{NC}$ \\
\hline & Public enlightenment on the impacts and control of climate change influencing activities & 23 & M & $\mathrm{A} / \mathrm{G}$ & $\mathrm{NC}$ \\
\hline & Financial aids/Subsidizing agricultural inputs & 22 & A & $\mathrm{A} / \mathrm{G}$ & $\mathrm{NC}$ \\
\hline & Farm Insurance & 21 & A & Farmer & CI \\
\hline & Establishment of food grain reserves & 21 & A & $\mathrm{A} / \mathrm{G}$ & $\mathrm{NC}$ \\
\hline
\end{tabular}

F-Frequency (Ranked); T-Type; WI-Who is Involved; CF-Cost on Farming; A-Adaptation; M-Mitigation; CI-Cost Implicative; NCNon-Cost-Implicative; F\&A/G- Farmer and Agencies/Government; A/G-Agencies/Government

SN26. Adding the respective values of each trait for each rated strategy, SN9, SN23, and SN28, with cumulative values of 27,30 , and 30 , respectively, had the highest innovativeness index values (IIV) while SN26, with IIV of 16, was the least, as presented on Table 3. The higher the IIV of each rated strategy, the more aligned to foster AIS in the region.

\section{Discussion}

Economics of suggested strategies for coping with the impacts of climate change in the Niger Delta

As climate change became a serious issue affecting agriculture in the Niger Delta, several studies were 


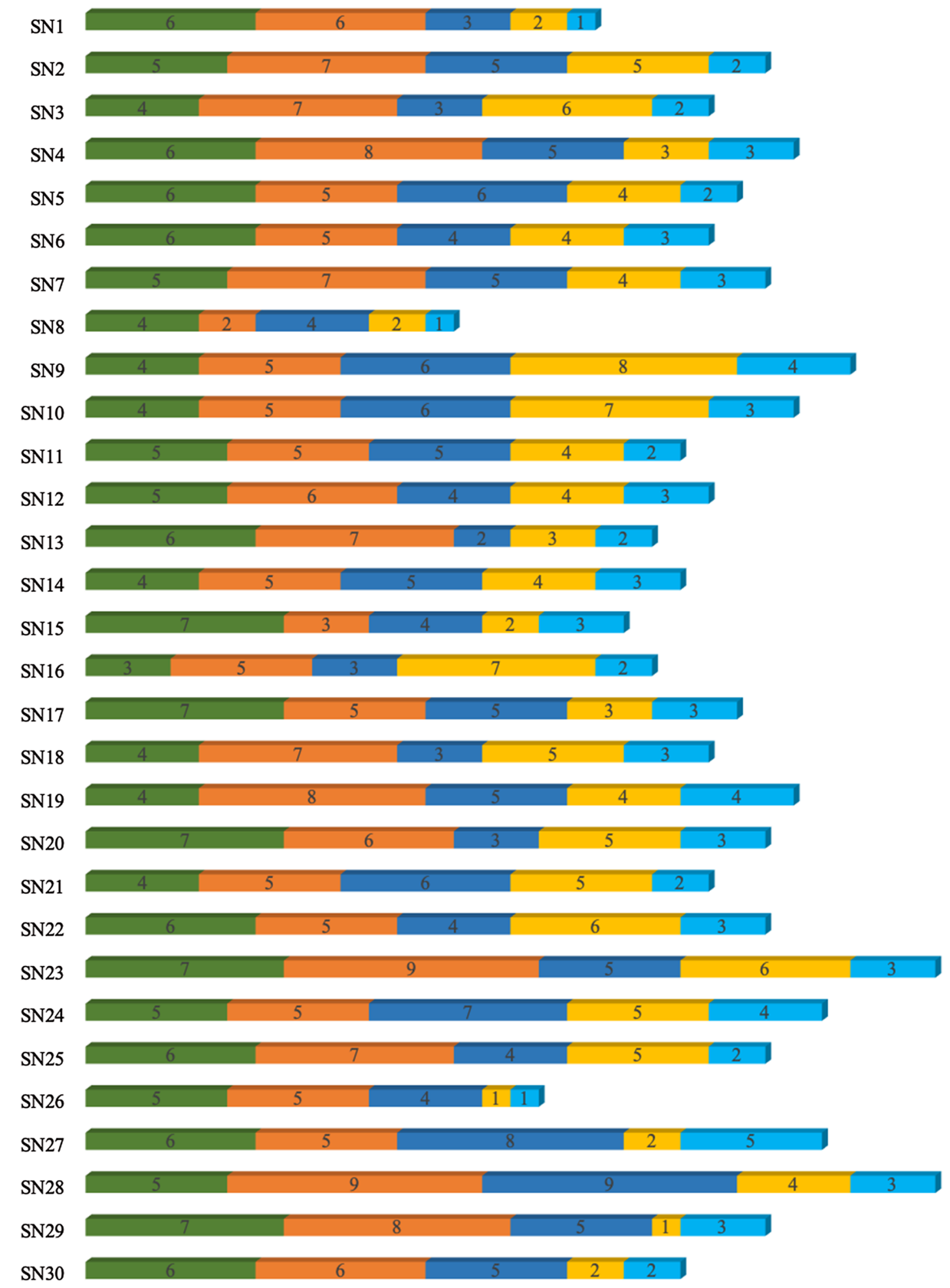

Novelty Improvement $\quad$ Economical $\square$ Widespread $\quad$ Interaction 
4Fig. 2 Innovativeness ratings of research recommended strategies. Source: Authors, 2021

carried out, providing recommendations to help farmers adjust, especially in crop production. In crop production, the cultivated farmland cannot be moved to a better location when conditions become unfavourable. The best approach would be to adjust production to the most suitable scenario by changing practices. Among the research-suggested strategies, the use of "irrigation/sinking borehole, construction of dam/ ditches for water collection" was the most recommended (see Table 2). Water availability is an important issue in crop farming, as water is very essential for plant development. Several studies (Apata, 2010; Franchito \& Rao, 2015; Molua \& Lambi, 2007; Pindyck, 2013; Rahman et al., 2017) have highlight the importance of adequate water supply for crop production. Authors like Bannayan et al. (2011) and Ikehi et al. (2021) further linked level of water availability to profitability of farming businesses and the sustainability of livelihood among rural farmers. Approaches to collection of water for irrigation in the region include construction of dykes and ridges to divert flood water away from cultivated lands when rainfall becomes excess or water bodies overflow their banks Jidauna et al., 2012; Ikehi et al., 2014). However, for a coastal region (Abisola, 2013; Idrisu, 2016) with frequent reports of inundation of rural farming communities (Uyigue \& Agho, 2007), the high number of studies suggesting artificial irrigation/water collection as a result of water scarcity could indicate a change in rainfall pattern such as timing, duration and intensity or that research is not aligning with reality in the region. If the latter is the case, it is likely that interactivity (thus, AIS) among stakeholders is weak in the region. The implication is that farm level interactions between farmers and other stakeholders are missing. Thus, recommendations for adaptation are not situation or community based. Other strategies recommended for adoption include changing planting and harvesting dates, changing species of crops cultivated, mix cropping, and planting trees. According to (Bannayan et al., 2011; Blanc, 2011; Mendlik \& Gobiet, 2016). Changing planting dates and cultivating improved varieties can help crop farmers avoid complete economic loss in climate change era. The likely dangers with these strategies are alterations in naturally synchronized events such as pollination and the possible (complete) replacement of local varieties of cultivated crops with exotic ones.

Strategies such as leaving production farming and migrating from climate risk prone areas are negative adaptations to crop production, though such were anticipated. According to (Myers, 2005), between 200 million to 1 billion "climate migrants" are expected worldwide by 2050 . Majority of the migrants will be youths who are supposed to take over farming from the aging generation. Such massive migration will create vacuums in the labour supply chain for farming in rural communities in developing countries where human power is the major source of power for farm operations. Table 2 also revealed other recommendations of research to help farmers and stakeholders adjust farming for better production.

Policy approach suggested by studies for combating climate change impacts by the government border on proclamation of laws banning or controlling deforestation, gas flaring, and bush burning. The proclamation of such laws as adaptation/mitigation steps are to control and correct actions leading to changing climates (IPCC, 2016). Enacting suitable laws can be followed with public enlightenment, setting up community-based implementation and monitoring agencies for effectiveness in any locality. However, (Emuedo \& Emuedo, 2018) laments the lack of strong political will of Nigerian states and governments to tackle climate change through strong policies. Though Nigeria has shown policy interest in addressing climate change such as the recognition of climate change as a factor threatening Nigerian economic prosperity and future development, agreeing to regional declaration by the African Ministerial Conference on the Environment (AMCAN) in May 2009, publication of the National Adaptation Strategy and Plan of Action on Climate Change for Nigeria (NASPA-CNN) in 2011, approval of a National Policy on Climate Change (NPCC) in 2013 and the signing of Kyoto-Protocol on climate change, among others. The NASPA-CNN strategy outlined responses to climate change in key areas such as agriculture (crops and livestock), freshwater resources, coastal water resources and fisheries, forests, biodiversity, migration and security, livelihoods, vulnerable groups, and education. However, it has not been effectively implementated. Like the NASPA-CNN, the level of implementation of the NPCC is likely not going to address rural climate change challenges owing to the fact that 
Table 3 Innovative Index Value (IIV) of research-recommended strategies and alignment to AIS

\begin{tabular}{|c|c|c|}
\hline $\mathrm{SN}$ & Suggested strategies & IIV \\
\hline 1 & Irrigation/sinking boreholes, construction of dams/ditches for water collection & 18 \\
\hline 2 & Protection of water sheds/mulching/cover cropping & 24 \\
\hline 3 & Increased labour/weeding & 22 \\
\hline 4 & Cultivation of improved varieties that are well acclimated to local factors & 25 \\
\hline 5 & Changing planting and harvesting dates & 23 \\
\hline 6 & Mixed farming/cropping and inter-cropping & 22 \\
\hline 7 & Planting of tree (reforestation/afforestation) & 24 \\
\hline 8 & Leaving farming/changing from production to marketing & 13 \\
\hline 9 & Land/crop rotation/bush fallow/shifting cultivation & 27 \\
\hline 10 & Use of organic manure & 25 \\
\hline 11 & Changing tillage practices (zero or minimum) & 21 \\
\hline 12 & Raising of dykes, contour bund, ridges and bridges to divert flood water & 22 \\
\hline 13 & Reclamation/draining of wetland/sand filling/culverting & 20 \\
\hline 14 & Stoppage/banning/controlling of deforestation/felling of trees/excess harvesting of timber/fire wood & 21 \\
\hline 15 & Migration from climate risk areas & 19 \\
\hline 16 & Increase in the use of chemicals herbicide, insecticide, pesticide & 20 \\
\hline 17 & Setting up windbreaks/shelter belts & 23 \\
\hline 18 & Increase usage of fertilizer & 22 \\
\hline 19 & Relying on weather information & 25 \\
\hline 20 & Construction of elevated homesteads and farmsteads & 24 \\
\hline 21 & Stopping/banning/controlling bush burning & 22 \\
\hline 22 & Changing planting depth & 24 \\
\hline 23 & Quick processing of crops to minimize post-harvest losses during storage & 30 \\
\hline 24 & Proclamation of laws reducing/banning/controlling activities such as gas flaring & 26 \\
\hline 25 & Expansion of cultivated area & 24 \\
\hline 26 & Adjusting sales price/Hedging & 16 \\
\hline 27 & Public enlightenment on the impacts and control of climate change influencing activities & 26 \\
\hline 28 & Financial aids/Subsidizing agricultural inputs & 30 \\
\hline 29 & Farm Insurance & 24 \\
\hline 30 & Establishment of food grain reserves & 21 \\
\hline
\end{tabular}

farmers were not part of the policy formulation, and the issue of poor or lacking physical and logistical infrastructure in the rural regions (Amobi \& Onyishi, 2015; Idrisu, 2016). With these policy implementation issues, the possibility of a functional AIS geared towards addressing climate change will remain low.

The existing build-up of greenhouse gases (GHG) means that the impacts of climate change are far from being over (IPCC, 2016); thus, present and future actions are required to adjust crop production to the existing and impeding impacts, whether in the Niger Delta or other regions in Africa and the world. Majority of the reported strategies are adaptations to existing conditions, and few aimed at preventing future occurrences. Adaptation strategies are usually shortlived and depend majorly on the efforts of the farmers rather than on government or other stakeholders. Examples include increasing labour/frequency of farm operations like weeding, increased use of chemicals, changing planting/harvesting dates, and changing planting depth. Adopting these strategies are likely why farming has become more labour and cost intensive, and more challenging. These findings buttress that of Nzeadibe et al. (2012) and Niles et al. (2016), who reported that farmers complaints of inability to adjust farming to existing climate change impacts have not been resolved to a reasonable level. This is arguably not the expected outcome 
especially as support for research in agriculture has risen in recent time (Rajalahti, 2009). While research continues to offer strategies for improving farming, the lack of responsive interactions among stakeholders likely results to less implementation and subsequently poor improvement of the sector (Devaux et al., 2018; Klerkx, 2015; Rajalahti et al., 2008; Rygnestad et al., 2009). According to Hall et al. (2003) and Hall (2012), agricultural research and development have tended to lag behind in the advancement of innovation processes and systems as researches in agriculture continue to focus on expanding inventions, sharing new knowledge and technologies rather than linking research to change processes for better farming.

Typical agricultural research generates knowledge and pass the information linearly to extension agents to reach the farmers. However, it is now recognized that farmers and other actors need to be actively involved in the research process, to ensure impactful and practical recommendations for improving rural economy (Pound \& Conroy, 2017). Rajalahti et al. (2008) argues that research outputs promote sustainable farming when they are presented in ways that the adoption involves collaborations with relevant support actors. Similarly, Saravanan and Suchiradipta (2017) explained that relying primarily on research knowledge and disseminating same through extension services alone cannot drive innovation in farming businesses. Aerni et al. (2015) opined that fostering a functional AIS in farming communities will help farmers in solving problems in their regions.

\section{Innovativeness of research-recommended strategies and alignment to AIS}

Findings of the study on innovativeness of suggested strategies is drawn from the ratings of the strategies for novelty, improvement, economics, widespread, and interaction (as presented on Fig. 2) and their possibility of fostering a sustainable AIS (as indicated by the IIV on Table 3). A good number of the suggested strategies appear to be new to the respondents. According to the World Bank (2012), innovations relate to the processes of mastering and implementing designs and products, and the approaches that are new- new to a region or a people. The emphasis is on newness of approach to those it was suggested to.
The suggested strategies rated high on novelty probably had a new dimension to the farmers' conventional approach to cultivation or completely brought about changes in indigenous practices and knowledge. This likely explains the more than average rating of most of the strategies on improvement. The possibilities are that for those who adopt the strategies, they tend to record some level of improvement in production output. According to OECD (2013), most novel or improved strategies have the potential to help farmers advance in farm production and resolve income uncertainties.

Though the extension agents rated a majority of the strategies to be novel and improve farming, adopting most of the strategies seems to be less economical for the farmers. An obvious reason for this is that most rural farmers in the Niger Delta region are indigent and cannot afford to cover the costs involved for "expensive" changes from conventional farm practices. According to Anandajayasekeram et al. (2010) any new creation or strategy of importance should have economic significance for the target class of users. This is an important trait of any newly introduced method of doing things. In regions with an active AIS, stakeholders quickly become aware of the inability of the farmers (through feedbacks) to implement such financially demanding strategies and may provide incentives for encouragement. The awareness and involvement of relevant stakeholders is a function of active interactions among farmers, research institutions, and other agencies to ensure widespread acceptability of the strategies.

General acceptability (widespread) of most strategies among farmers in the Niger Delta was rated low. This reveals a likely troubling gap existing between production and consumption of knowledge in agriculture. Implications are that agricultural researches in the region continue to make recommendations for dealing with climate change issues, but adoption remains at minimal levels. Generating and sharing new knowledge is important, yet most new knowledge that can enhance productivity and sustainability in farming is often not widespread (Sulaiman, 2015). A likely cause for this is the lack of interactivity among source of generation, the point of usage and other actions/agents in between. According to Devaux et al. (2018), researches in agriculture may be concerned with the supply of new knowledge; however, such knowledge may or may not be used in practice 
for several reasons. In line with this, Toillier et al. (2018) suggests that researchers hoping to make significant impacts in agriculture are to move beyond the traditional role of generating knowledge to work more closely with actors, such as farmers, who are supposed to utilize the knowledge at farm levels. Possibly, a follow-up on the application of research findings at farm levels can ensure steady flow of meaningful feedback and foster useful interactions among stakeholders. Like widespread of the strategies, interactions among stakeholders at play or needed for the adoption of most suggested strategies were also rated low. On close comparison with other traits, interactivity was the least rated. Indications are that interactions among stakeholders such as farmers, research institutions and other agencies in the region are completely lacking or very limited. This poses a serious issue for agriculture and research in general.

The poor interactivity among stakeholders likely has significant effects on the level of adoption of the strategies in the region. It is suggested that a sustainable system for encouraging the adoption of suitable strategies involves active participation of actors at various points (Anandajayasekeram et al., 2010; Klerkx et al., 2010; Saravanan \& Suchiradipta, 2017; Schut et al., 2015). It is arguable that even when other traits are well rated but interaction remains low, the entire success of adoption of the strategies could still be hampered. This is likely so as effective interactions among stakeholders ensure flow of the right information, responsive feedback, collaborations and supports when needed. Interactions with research stakeholders, for example, could have provided resourceful feedback for modifying strategies to suit local conditions. Furthermore, the involvement of government and some relevant (non-governmental) agencies could have led to policy initiatives that could drive and possibly create stimulus (motivation) to encourage the adoption of suggested strategies. Of the thirty items presented on Table 3, only twelve items had innovative index values (IIV) greater or equal to twenty-five. For a region rich enough to be described as an area most suitable for the cultivation of important staple foods (Abisola, 2013; Ifeanyieze et al., 2016; Rosemary et al., 2012), lower IIV of a suggested strategy indicate poor alignment to AIS in the region. AIS features a blend of actors in the agricultural and associated sectors that works towards introducing new or improving products and processes with emphasis on social and economic significance while drawing supports from institutions and policies (Agwu et al., 2008; Amungwa, 2018; Birner et al., 2009; Lobell et al., 2008; Pigford et al., 2018; Tropical Agriculture Platform, 2016). Therefore, as the innovative indexes of the strategies remain lowly rated, indications are that the processes of enhancing agricultural productions following research recommendations in the region have not performed satisfactorily to foster a sustainable AIS. Promoting the adoption of innovative strategies should be purposeful and focused on creating and sustaining interactions and linkages among actors in line with favourable policies and environment for implementation (Grovermann et al., 2019; Klerkx, 2015; Nederlof et al., 2011; Onu \& Ikehi, 2016; Saravanan \& Suchiradipta, 2017; Weyori et al., 2017).

\section{Conclusions and recommendations}

The study adds to the discussion of climate change and AIS at rural levels, particularly in the climate change prone and oil rich Niger Delta region. The efforts of authors in the region in proffering solution to climate change through research are commendable. However, generating new or modify existing knowledge and publishing (sharing) same only satisfies a section of the multi-sectional but interconnected AIS system. Focusing primarily on generating findings especially where there are significant costs involved for adoption, missing policies/enabling environment and poor interactivity among stakeholders limits the potentials for a functional AIS and consequently food production in any region. A way forward would be to generate new or modify indigenous knowledge, share them and as well involve (or detail the involvement) of relevant governmental and non-governmental agencies for onward intervention. It is important to emphasize that the role of the researchers is to provide solutions to problems through sound research approaches. The outputs are in general scientific papers and flyers/policy briefs/technical briefs for the policy-makers and extension services. The interventions (application and upscaling of the solutions/ innovations) are the mandate of the policy-maker and extensions agents. Therefore, interventions could be policy formulation to drive the process of implementation, attract relevant agencies to support farming 
or provide motivation for stimulating the interest of the end users to adopt the strategies while ensuring a smooth interplay among stakeholders. This is why it will be important and possibly more beneficial to the farmers, as the end users, when the strategies recommended conform to local norms or offer gradual shift from conventional practices. This means that researches should aim at proffering climate change solutions by first analysing existing issues within the locality then recommend condition- or environmentspecific adjustment strategies for farming in a region.

The study, thus, suggests the need for a paradigm shift in climate change researches. New studies should report impact assessment of recommended strategies so that research can show, then shape how climate change adaption and mitigations strategies are practicable at farm levels. Finally, an important aspect of future research with recommendations for adoption should account for capacity of the rural farmers to adopt and adapt. This is important to ensure that published papers in the region on climate change are not only academic articles for promotion assessment of the authors or for improving knowledge reserve but also have practicable implication(s), if and when relevant national/international (non-/governmental) agencies decide to rely on research findings to develop or update policy framework or offer interventions for tackle climate change as it affects food production in the region and beyond.
Funding No funding for this study.

Availability of data and material Data generated for this study is presented as tables and figures in the manuscript.

Code availability Not applicable.

\section{Declarations}

Conflict of interest The authors declare that they have no known competing financial interests or personal relationships that could have appeared to influence the work reported in this paper.

Ethics approval Committee (DAEREC) of the University of Nigeria, Nsukka, and the decision was communicated to the lead researcher through a memo (UNN/AED/REC/20/0087).

Consent for publication The authors agreed that the findings of the study should be published.

Consent to participate The lists of extension agents for each state were obtained from Agricultural Development Agency of the Ministry of Agriculture of the states, following a formal request and subsequent approval to use the extension agents as respondents for the study. Potential respondents were contacted through telephone calls to seek their consent to participant in the study.

\section{Appendix}

See Fig. 3.
Fig. 3 Map of Nigeria numerically showing states typically considered part of the Niger Delta. Source: Gozar at the Englishlanguage Wikipedia, CC BY-SA 3.0, https://commo ns.wikimedia.org/w/index. php?curid $=1674115$

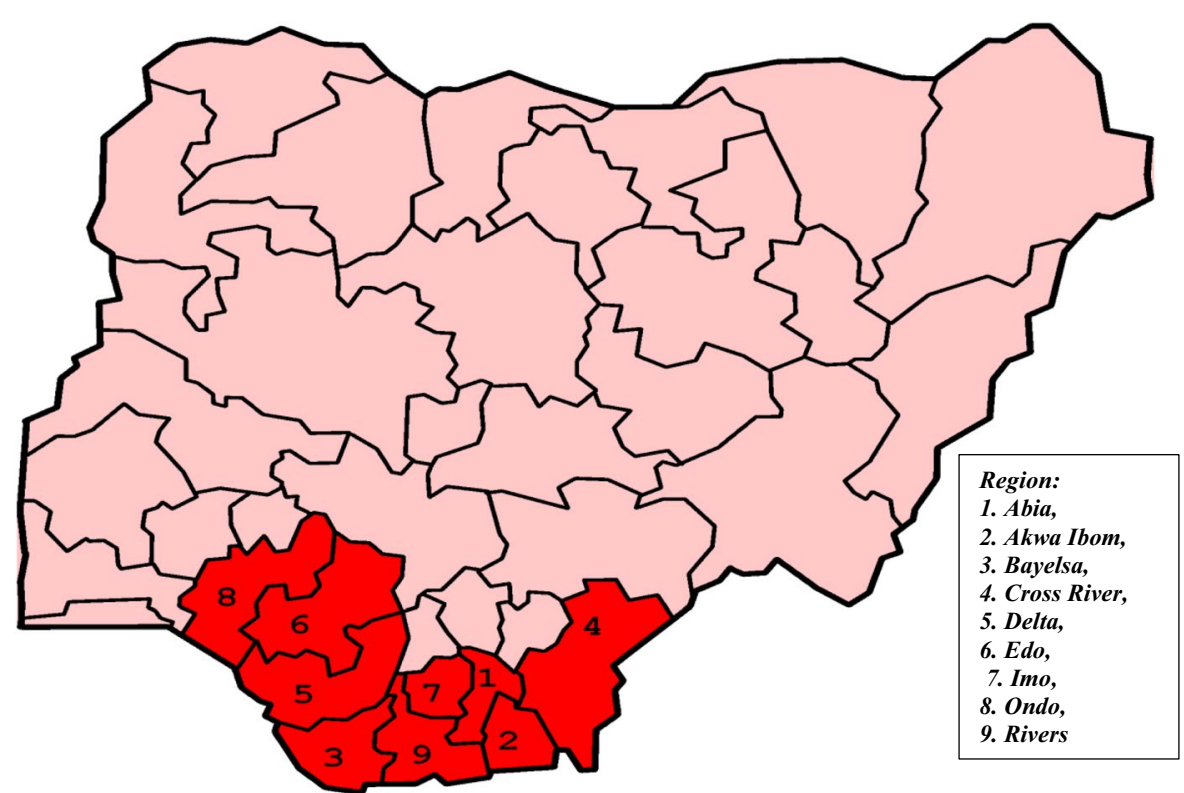




\section{References}

Abisola, A. (2013). Where cultivation meets conflict: Farming in the Niger Delta. Nourishing the planet. http:// blogs. worldwatch.org/nouri shing theplanet/wherecultivation-meetsconflict-farming-in-the-niger-delta/. Accessed 21 March 2020.

Aerni, P., Nichterlei, K., Rudgard, S., \& Sonnino, A. (2015). Making agricultural innovation systems (AIS) work for development in tropical countries. Sustainability, 7, 831-850. https://doi.org/10.3390/su7010831

Agbonifo, P. (2016). Oil spills injustices in the Niger delta region: Reflections on oil industry failure in relation to the united nations environment programme (UNEP) report. International Journal of Petroleum and Gas Exploration Management, 2(1), 26-37.

Agwu, A. E., Dimelu, M. U., \& Madukwe, M. C. (2008). Innovation system approach to agricultural development: Policy implications for agricultural extension delivery in Nigeria. African Journal of Biotechnology, 7(11), 1604-1611.

Amobi, D., \& Onyishi, T. (2015). Governance and climate change in Nigeria: A public policy perspective. Journal of Policy and Development Studies, 9(2), 199-201.

Amungwa, F. A. (2018). Appraisal of innovations in agricultural extension and advisory services in cameroon. Journal Advanced Plant Sciences., 1, 204.

Anandajayasekeram, P. (2011). The role of agricultural R\&D within the agricultural innovation systems framework. In Agricultural science and technology indicator conference working paper 6 . Ghana, Accra.

Anandajayasekeram, P., Puskur, R., \& Zerfu, E. (2010). Applying innovation system concept in agricultural research for development: A learning module. International Livestock Research Institute (ILRI).

Apata, T. G. (2010). Effects of global climate change on Nigerian agriculture: An empirical analysis. CBN Journal of Applied Statistics, 2(1), 31-50.

Atubi, A. O. (2015). Effects of oil spillage on human health in producing communities of Delta State, Nigeria. European Journal of Business and Social Sciences, 4(8), 14-30.

Aweto, A. O. (2011). Agriculture in urhoboland. http://www. waado.org/geography/Agriculture/Agruclture-Aweto. html. Accessed 21 March 2020.

Baede, A. P. (2015). Glossary on climate change. Annex I. Intergovernmental Panel on Climate Change (IPCC) Report. Netherlands Edition (p. 942).

Bannayan, M., Lotfabadi, S. S., Sanjani, S., Mohamadian, A., \& Aghaalikhani, M. (2011). Effects of precipitation and temperature on crop production variability in northeast Iran. Journal Biometeorology, 55(3), 387-401. https:// doi.org/10.1007/s00484-010-0348-7

Birner, R., Davis, K., Pender, J., Nkonya, E., Anandajayasekeram, P., Ekboir, J., Mbabu, A., Spielman, D., Horna, D., \& Benin, S. (2009). From best practice to best fit: A framework for analyzing agricultural advisory services worldwide. Journal of Agricultural Extension and Education, 15(4), 341-355.
Blanc, E. (2011). The impact of climate change on crop production in Sub-Saharan Africa. University of Otago. http://hdl.handle.net/10523/1724. Accessed 13 April 2021.

Devaux, A., Torero, M., Donovan, J., \& Horton, D. (2018). Agricultural innovation and inclusive value-chain development: A review. Journal of Agribusiness in Developing and Emerging Economies, 8(1), 99-123. https://doi.org/ 10.1108/JADEE-06-2017-0065z

Ebegbulem, J. C., Ekpe, D., \& Adejum, T. O. (2013). Oil exploration and poverty in the Niger delta region of Nigeria: A critical analysis. International Journal of Bus \& Social Science, 4(3), 279-280.

Emuedo, O. A., \& Emuedo, C. O. (2018). Biodiversity and oil activities in the Niger Delta region of Nigeria. Journal of Geography, Environment and Earth Science International, 14(3), 1-8.

Enete, I. C. (2014). Impacts of climate change on agricultural production in Enugu state Nigeria. Journal Earth Science Climate Change, 5, 234. https://doi.org/10.4172/21577617.1000234

Foundation for Partnership Initiatives in the Niger Delta (PIND). (2011). A report on economic opportunities in the Niger Delta. https://ndpifoundation.org/wp-content/uploa ds/2018/09/Economic-Opportunities-in-the-Niger-Delta. pdf. Accessed 12 April 2021.

Franchito, S., \& Rao, V. (2015). Studies of climate change with statistical-dynamical models: A review. American Journal of Climate Change, 4, 57-68. https://doi.org/10.4236/ajcc. 2015.41006

Graham, S., \& Perin, D. (2007). A meta-analysis of writing instruction for adolescent students. Journal of Educational Psychology, 99(3), 445-476.

Grovermann, C., Wossen, T., Muller, A., \& Nichterlein, K. (2019). Eco-efficiency and agricultural innovation systems in developing countries: Evidence from macro-level analysis. PLoS ONE, 14(4), e0214115. https://doi.org/10. 1371/journal.pone.0214115

Hall, A. (2007). Challenges to strengthening agricultural innovation systems: Where do we go from here? Maastricht Economic and Social Research and Training Centre on Innovation and Technology. UNU-MERIT working papers \#2007-038.

Hall, A. (2012). Partnerships in agricultural innovation: Who puts them together and are they enough? In Improving agricultural knowledge and innovation systems: OECD conference proceedings. OECD Publishing.

Hall, A., Sulaiman, V., Clarke, N., \& Yoganand, B. (2003). From measuring impact to learning institutional lessons: An innovation systems perspective on improving the management of international agricultural research. Agricultural Systems, 78, 213-241.

Idrisu, B. (2016). Climate change challenges in Nigeria and the implications for energy. http://www.nairaland.com/22860 29/climate-change-challenges-nigeria-implications

Ifeanyieze, F. O., Alkali, M., Okoye, R. N., \& Ikehi, M. E. (2016). Altered climate and livelihood of farming families in Niger Delta region of Nigeria. African Journal of Agricultural Research, 11(10), 882-888. https://doi.org/10. 5897/AJAR2015.10716 
Ikehi, M. E., Ifeanyieze, F. O., \& Onu, F. M. (2021). Econometrics of climate change variables on the net income of agribusinesses in the Niger Delta area of Nigeria. International Journal of Big Data Mining for Global Warming. https://doi.org/10.1142/S2630534820500096

Ikehi, M. E., Onu, F. M., Ifeanyieze, F. O., Paradang, P. S., Nwakpadolu, M. G., Ekenta, L. U., \& Nwankwo, C. U. (2019). Survey on sample sizes of postgraduate theses in agricultural education and extension in universities in Nigeria. Journal of Extension Education, 31(1), 62006208. https://doi.org/10.26725/JEE.2019.1.31.6200. 6208

Ikehi, M. E., Onu, F. M., Ifeanyieze, F. O., \& Paradang, S. P. (2014). Farming families and climate change issues in Niger Delta Region of Nigeria: Extent of impact and adaptation strategies. Journal of Agricultural Sciences, 5, 1140-1151. https://doi.org/10.4236/as.2014.512124

Intergovernmental Panel on Climate Change (IPCC). (2016). AR5 synthesis report. 2016/PR/1. http://ipcc.ch/pdf/asses sment-report/ar5/syr/SYR_AR5_FINAL_full_wcover.pdf. Accessed 13 April 2021.

Ito, E. E., \& Ugbome, I. L. (2017). Impact of gas flaring on biodiversity in Niger Delta, Nigeria. Nigerian Journal of Science and Environment, 15(1), 147-154.

Jackson, J., Akujobi, T., \& Dan, A. U. (2016). Crude oil exploration and underdevelopment in Nigeria: A resource curse analysis. Technology Science Review, 7, 31-44.

Jidauna, G. G., Dabi, D. D., \& Dia, R. Z. (2012). The effect of climate change on agricultural activities in selected settlements in the Sudano-Sahelian Area of Nigeria Scholars Research Library. Archives of Applied Science Research, 4(1), 703-713.

Junk, J., Kouadio, L., Delfosse, P., \& Jarroudi, M. E. (2016). Effects of areal climate change on brown rust disease in winter wheat. Climatic Change, 135, 439-451. https://doi. org/10.1007/s10584-015-1587-8

Klerkx, L. (2015). Agriculture Innovation Systems for successful innovationap-Examples from around the Globe. Presentation at the University of Auckland, 20 February 2015.

Klerkx, L., \& Aarts, N. (2013). The interaction of multiple champions in orchestrating innovation networks: Conflicts and complementarities. Technovation, 33, 193-210.

Klerkx, L., Aarts, N., \& Leeuwis, C. (2010). Adaptive management in agricultural innovation systems: The interactions between innovation networks and their environment. Agricultural Systems, 103, 390-400.

Lambert, K. D. (2014). Historical impacts of precipitation and temperature on farm production in Kansas. Journal of Agricultural and Applied Economics, 46(4), 439-456.

Linden, O., \& Pålsson, J. (2013). Oil contamination in Ogoniland, Niger Delta. Ambio. https://doi.org/10.1007/ s13280-013-0412-8

Lobell, D. B., Burke, M. B., Tebaldi, C., Mastrandrea, M. D., Falcon, W. P., \& Naylor, R. L. (2008). Prioritizing climate change adaptation needs for food security in 2030. Science, 319(5863), 607-610.

Mach, K. J., Mastrandrea, M. D., Bilir, T. E., \& Field, C. B. (2016). Understanding and responding to danger from climate change: The role of key risks in the IPCC AR5. Climatic Change. https://doi.org/10.1007/s10584-016-1645-X
Mendlik, T., \& Gobiet, A. (2016). Selecting climate simulations for impact studies based on multivariate patterns of climate change. Climatic Change, 135, 381-393. https:// doi.org/10.1007/s10584-015-1582-0

Molua, E. L., \& Lambi, C. M. (2007). The economic impact of climate change on agriculture in Cameroon. The World Bank Development Research Group on Sustainable Rural and Urban Development Team. Policy research working paper 4364.

Moram, A. (2011). Climate change adaptation in Nigeria key considerations for decision making. Working Paper. Conrad Adenaver Sifting, Nigeria Office

Myers, N. (2005). Environmental refugees: An emergent security issue. Presented at the 13th economic forum, Prague (pp. 23-27).

Nederlof, S., Wongtschowski, M., \& van der Lee, F. (Eds.). (2011). Putting heads together: Agricultural innovation platforms in practice. Bulletin 396. KIT Publishers.

Niles, M. T., Brown, M., \& Dynes, R. (2016). Farmer's intended and actual adoption of climate change mitigation and adaptation strategies. Climatic Change, 135, 277-295. https://doi.org/10.1007/s10584-015-1558-0

Nwilo, P. C., \& Olusegun, T. B. (2007). Impacts and management of oil spill pollution along the Nigerian coastal areas. International Federation of Surveyors.

Nzeadibe, T. C., Egbule, C. L., \& Chukwuone, N. A. (2012). Indigenous innovations for climate change adaptation in the Niger Delta area of Nigeria. Environment, Development and Sustainability, 14, 901. https://doi.org/10.1007/ s10668-012-9359-3

Okringbo, J. I., \& Ominikari, A. G. (2017). Effect of climate change on arable crop production in Bayelsa State, Nigeria. Journal of Community and Communication Research, 2(1), 23-27.

Onu, F. M., \& Ikehi, M. E. (2016). Mitigation and adaptation strategies to the effects of climate change on the environment and agriculture in Nigeria. IOSR Journal of Agriculture and Veterinary Science, 9(4), 26-29. https://doi.org/ 10.9790/2380-0904022629

Ordinioha, B., \& Brisibe, S. (2013). The human health implications of crude oil spills in the Niger Delta, Nigeria: An interpretation of published studies. Nigerian Medical Journal, 54(1), 10-16.

Organization for Economic Cooperation Development (OECD). (2013). Agricultural innovation systems: A framework for analysing the role of the government. OECD Publishing. https://doi.org/10.1787/9789264200 593-en

Osuoha, C. A., \& Fakutiju, M. A. (2017). Gas flaring in Niger Delta region of Nigeria: Cost, ecological and human health implications. Environmental Management and Sustainable Development, 6(2), 390-410. https://doi.org/10. 5296/emsd.v6i2.11662

Paustian-Underdahl, S. C., Walker, L. S., \& Woehr, D. J. (2014). Gender and perceptions of leadership effectiveness: A meta-analysis of contextual moderators. Journal of Applied Psychology, 99(6), 1129-1145.

Pigford, A. E., Hickey, G. M., \& Klerkx, L. (2018). Beyond agricultural innovation systems? Exploring an agricultural innovation ecosystems approach for niche design and development in sustainability transitions. Agricultural 
Systems, 164, 116-121. https://doi.org/10.1016/j.agsy. 2018.04.007

Pindyck, R. S. (2013). Climate change policy: What do the models tell us? Journal of Economic Literature, 51(3), 1-23. https://doi.org/10.1257/jel.51.3.860

Pound, B. \& Conroy, C. (2017). The innovation systems approach to agricultural research and development. In B. Pound, S. Snapp (Eds.), Agricultural systems, chapter 11. Elsevier. https://doi.org/10.1016/B978-0-12-802070-8. 00011-6.

Rahman, M. A., Kang, S., Nagabhatla, N., \& Macnee, R. (2017). Impacts of temperature and rainfall variation on rice productivity in major ecosystems of Bangladesh. Agriculture \& Food Security. https://doi.org/10.1186/ s40066-017-0089-5

Rajalahti, R. (2009). Promoting agricultural innovation systems approach: The way forward. The World Bank. http:// knowledge.cta.int/Dossiers/S-T-Policy/Innovation-syste $\mathrm{ms} /$ Feature-articles/Promoting-Agricultural-InnovationSystems-Approach-The-Way-Forward. Accessed 9 March 2020.

Rajalahti, R., Janssen, W., \& Pehu, E. (2008). Agricultural innovation systems: From diagnostics toward operational practices (p. 38). The World Bank Publications.

Rosemary, N. O., Okoh, P. N., Michael, I., Ajibefun, I. A., Idehen, K. I., Ajieh, P. C, \& Osakwuni, E. U. (2012). Assessment of impacts, vulnerability, adaptive capacity and adaptation to climate change in the Niger Delta area, Nigeria. http://rurallinkage.net/project_details.php?proje ct_id=3\&pix_id=4\&category_id=2. Accessed 21 March 2020.

Rygnestad, H., Rajalahti, R., Ragasa, C., \& Pehu, E. (2009). The sustainable agricultural systems, knowledge and institutions (SASKI) FYO8 portfolio review. World Bank.

Saleh, M. A., Ashiru, M. A., Sanni, J. E., Ahmed, T. A., \& Muhammad, S. (2017). Risk and environmental implications of oil spillage in Nigeria (Niger-Delta Region). International Journal of Geography and Environmental Management, 3(2), 44-53.

Saravanan, R. \& Suchiradipta, B. (2017). Agricultural innovation systems: Fostering convergence for extension. MANAGE Bulletin 2 (2017). National Institute of Agricultural Extension Management.

Schick, L., Myles, P. \& Okelum, O.E. (2018). Gas flaring continues scorching Niger Delta. www.dw.com/en/gas-flari ng-continues-scorching-niger-delta/a-46088235. Accessed 22 Jan 2020.
Schut, M., Klerkx, L., Rodenburg, J., Kayeke, J., Hinnou, L. C., Raboanarielina, C. M., Adegbola, P. Y., Ast, A., \& Bastiaans, L. (2015). RAAIS: Rapid Appraisal of Agricultural Innovation Systems (Part I) A diagnostic tool for integrated analysis of complex problems and innovation capacity. Agricultural Systems, 132(2015), 1-11. https:// doi.org/10.1016/j.agsy.2014.08.009s

Stakeholderdemocracy. (2020). Overview of the Niger Delta. https://www.stakeholderdemocracy.org/the-niger-delta/\#: $\sim:$ text=Demographic\%20and $\% 20$ geography,in $\% 20$ the $\%$ 20Niger\%20Delta\%20varies. Accessed 30 Nov 2020.

Sulaiman, R. V. (2015). Agricultural innovation systems. Note 13. GFRAS Good Practice Notes for Extension and Advisory Services. GFRAS

Toillier, A., Faure, G., \& Chia, E. (2018). Designing and organizing support for collective innovation in agriculture-Chapter 8. In G. Faure, Y. Chiffoleau, F. Goulet, L. Temple, \& J. Touzard (Eds.), Innovation and development in agricultural and food systems. Éditions Quæ.

Tropical Agriculture Platform. (2016). Common framework on capacity development for agricultural innovation systems: Synthesis document. CAB International.

Ugolor, D. (2004). Oil of poverty in the Niger Delta. African Network for Environment and Economic Justice, 24(2), 243-348.

UNDP. (2006). The Niger delta human development report. UNDP Nigeria. http://hdr.undp.org/sites/default/files/niger ia_hdr_report.pdf. Accessed 13 Sept 2020.

Uyigue, E., \& Agho, M. (2007). Coping with climate change and environmental degradation in the Niger Delta of Southern Nigeria. CREDC Press.

Weyori, A. E., Amare, M., Garming, H., \& Waibel, H. (2017). Agricultural innovation systems and farm technology adoption: Findings from a study of the Ghanaian plantain sector. The Journal of Agricultural Education and Extension, 24(1), 65-87. https://doi.org/10.1080/1389224X. 2017.1386115

World Bank. (2012). Agricultural innovation systems; An investment sourcebook. The World Bank. https://doi.org/ 10.1596/978-0-8213-8684-2

Publisher's Note Springer Nature remains neutral with regard to jurisdictional claims in published maps and institutional affiliations. 